\title{
ORIGINAL
}

\section{Distribution of parasympathetic nerve terminals in the rat submandibular gland}

\author{
Haruki Miyao \\ Department of Physiology, Osaka Dental University \\ (Chief : Prof. Yo Yoshida) \\ 1-5-31, Otemae, Chuo-ku, Osaka 540, Japan
}

〔Received on September 30, 1995 ; Accepted on December 11, 1995〕

Key words : choline acetyltransferase/interleukin 3 /immunohistochemistry/submandibular gland/rat

\begin{abstract}
I examined the distribution of cholinergic neuron terminals in the rat submandibular gland. Immunohistochemical procedures with a monoclonal antibody against choline acetyltransferase (ChAT) were used to determine the ultrastructural features of the putatively cholinergic axons. Either the streptavidin biotin-peroxidase complex method or the post-embedding staining with protein A-colloidal gold method was used for immuno-staining. The reaction was too weak to detect using conventional methods for ChAT. Interleukin 3 (IL-3) was used to enhance immunohisto-staining of peripheral cholinergic axons. Good results were obtained with IL-3 treatment. The submandibular ganglions and nerve bundles were both close to the main duct, and both were immuno-reactive to ChAT.

Although a number of ChAT positive fibers were seen within the acini and intercalated ducts of the submandibular parenchyma, they were not in other duct cells. ChAT positive terminals of adrenergic axons were detected by prior treatment with 5-hydroxydopamine (5-OHDA). Axons containing vesicles, not only aminergic but also occasionally cholinergic, were found adjacent to the endothelial cells of blood vessels. Although axons containing dense cores in their vesicles were noted at the basement membrane of acinar and duct cells, ChAT positive terminals were seen in both acinar and intercalated duct cells.

These findings suggest that immunocytochemical staining using ChAT monoclonal antibodies with IL-3 treatment is a useful technique for detection of cholinergic peripheral nerve fibers in the submandibular gland.
\end{abstract}

抄録：唾液腺に分布する交感神経, 副交感神経および一次感覚神経の機能を形態学的に検索するための分別方 法はまだ確立されていない。そこで，ラット顎下腺を用いてコリン作動性神経の同定およびその分布を choline acetyltransferase (ChAT) モノクローナル抗体を用いて免疫組織化学的に検索した。腺組織中の ChAT 活性を 高めるために Interleukin-3（IL-3）で前処理すると，顎下腺組織中におけるChAT 陽性神経線維が腺房部細胞， 介在部導管細胞および血管壁周囲に光顕的に観察された。また，5-hydroxydopamine (5-OHDA) を投与して， アミン含有神経線維と ChAT 陽性神経線維との電顕的識別を試みると, 血管の周囲に近接してアドレナリン作動 性終末もみられ, 腺房部細胞および介在部導管細胞の基底膜には 5-OHDA 陽性終末と ChAT 陽性終末とが隣 接して分布していた。

以上の結果から, 腺組織を IL-3 で前処理すると免疫組織化学的反応性が上昇し, コリン作動性末梢神経終末 の同定に有効であることが示唆された。

\section{Introduction}

When secretory impulses induce salivary secretion, facilitation of gland metabolism, vasodilation and enhancement of glandular activity are observed in the salivary gland. Sympathetic, parasympathetic, and primary sensory ${ }^{1)}$ neurons are distributed throughout 
the salivary gland. Not only are these three nerve fibers distributed in the glandular, vascular endothelial, and myoepithelial cells, but they also seem to regulate effector cells by their neuropeptide secretions ${ }^{2,3}$. However, no method of distinguishing these three nerve fibers has as yet been developed for the salivary gland. The principal function of the salivary gland is secretion of water, and in this regard, the parasympathetic component is the most important ${ }^{4,5}$.

Although acetylcholine was identified as a neurotransmitter ${ }^{6}$ many years ago, knowledge of the morphology and function of peripheral cholinergic neurons is still obscure. This is mainly because there have been technical difficulties in visualizing cholinergic systems at the cellular level ${ }^{7}$. The immunohistochemical method for choline acetyltransferase (ChAT) is believed to offer the most reliable method of localizing cholinergic systems ${ }^{8}$. Available data on cholinergic innervation of the submandibular gland are based on acetylcholinesterase (AChE) histochemistry ${ }^{9}$. However, $\mathrm{AChE}$ is a less reliable marker for cholinergic elements than ChAT ${ }^{10,11)}$. There seem to have been no reports on the distribution of ChAT in the salivary gland, perhaps owing to uncertainties concerning the relative insensitivity of ChAT immunohistochemistry.

In this study, methods for the immunohistochemical detection of ChAT in the peripheral nerve neurons were developed. These methods were then applied to determine the distribution of parasympathetic nerve fibers in the rat submandibular gland.

\section{Materials and Methods}

Adult male Wistar rats weighing 250 300 g were used, and all surgical procedures were performed under anesthesia with intraperitoneal injection of sodium pentobarbital $(50 \mathrm{mg} / \mathrm{kg})$.

\section{Fixation}

The animals were perfused through the heart with ice-cold $0.1 \mathrm{M}$ phosphate buffered ( $\mathrm{pH}$ 7.4) saline (PBS), and then for $5 \mathrm{~min}$. with a mixture of $4 \%$ paraformaldehyde, $15 \% \mathrm{v} / \mathrm{v}$ saturated picric acid, and
$0.35 \%$ glutaraldehyde in PBS followed by the same containing $4 \%$ paraformaldehyde alone for $10 \mathrm{~min}$. Immediately after perfusion, the submandibular gland was removed, postfixed in PBS containing $4 \%$ paraformaldehyde with saturated $15 \% \mathrm{v} / \mathrm{v}$ picric acid for approximately 24 to $48 \mathrm{~h}$, and then stored in a solution of $15 \%$ sucrose in PBS containing $0.3 \%$ Triton $\mathrm{X}-100$ at $4^{\circ} \mathrm{C}$ for $24 \mathrm{~h}$. Gland blocks were sectioned on a freezing microtome of $20 \mu \mathrm{m}$ thickness.

\section{ChAT Immunohistochemistry}

Immunohistochemical staining of the sections was done using several high titer monoclonal antibodies to ChAT (Boehringer Mannheim, Germany ; Chemicon, USA).

Pre-embedding method: Sections were rinsed, and then stored in PBS containing $0.1 \%$ sodium azide. Endogenous peroxidase activity was blocked by incubation for $30 \mathrm{~min}$. in $3 \%$ hydrogen peroxidase in $10 \%$ methanol. After rinsing in PBS, non-specific binding of immunoglobulins was blocked by incubation with $10 \%$ normal goat serum. The sections were then

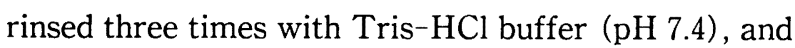
pre-treated with papain (Sigma, USA, $1 \mathrm{U} / \mathrm{m} l$ in PBS) for $30 \mathrm{~min}$. at room temperature. The sections were sequentially incubated with anti ChAT monoclonal antibody solution diluted $1: 5$ or $1: 10$ in PBS containing $1 \%$ fetal calf serum and $2 \%$ bovine serum albumin and $0.5 \%$ Triton $\mathrm{X}-100$ at $4^{\circ} \mathrm{C}$ for $24 \mathrm{~h}, 4^{\circ} \mathrm{C}$ for $48 \mathrm{~h}$, or $37^{\circ} \mathrm{C}$ for $2 \mathrm{~h}$; biotinylated rabbit anti-mouse $\operatorname{IgG}+\operatorname{Ig} A+\operatorname{IgM}$ diluted in PBS containing $1 \%$ fetal calf serum for $10 \mathrm{~min}$. at room temperature ; and then streptavidin biotin-peroxidase complex (1\%) in PBS for $5 \mathrm{~min}$. at room temperature. The peroxidase was visualized by incubating the sections with $0.05 \% \mathrm{DAB}$ in Tris-buffer ( $\mathrm{pH} 7.6$ ) containing $0.02 \% \mathrm{CoCl}_{2} \cdot 6 \mathrm{H}_{2} \mathrm{O}$, $0.04 \% \mathrm{NiCl}_{2} \cdot 6 \mathrm{H}_{2} \mathrm{O}$, and $0.01 \% \mathrm{H}_{2} \mathrm{O}_{2}{ }^{12,13}$. After washes in PBS, the sections were post-fixed with $1 \%$ osmium tetroxide $\left(\mathrm{OsO}_{4}\right)$, and after dehydration in graded ethanols, embedded in ERL 4206-Quetol $653^{14}$. Sections were selected using the light microscope and processed for ultrathin sectioning.

Post-embedding method: Ultrathin sections without post-fixation by $\mathrm{OsO}_{4}$ were incubated on $0.05 \mathrm{M}$ lysine in PBS for $10 \mathrm{~min}$. at room temperature. The 
grids were transferred onto drops of incubation buffer supplement with $5 \%$ fetal calf serum for $15 \mathrm{~min}$. at room temperature, and then again transferred onto drops of $1: 5$ dilution of monoclonal antibody to ChAT $(5 \mu \mathrm{g} / \mathrm{m} l)$ for $24 \mathrm{~h}$ at $4^{\circ} \mathrm{C}^{15)}$. After washing with PBS, the grids were treated with drops of protein Acolloidal gold ( $10 \mathrm{~nm}$ : Aurion, Belgium) in PBS containing $5 \%$ fetal calf serum for $12 \mathrm{~h}$ at $4^{\circ} \mathrm{C}$. The grids were then washed with PBS. Ultrathin sections were observed in a Hitachi $\mathrm{H}-7100$ electron microscope (Electron Microscope Facilities: Institute of Dental Research, Osaka Dental University).

\section{Controls}

The following controls were included: (a) omission of primary antiserum, and (b) substitution of primary antiserum with nonimmune sera (DAKO, Germany) diluted $1: 500$ in blocking buffer including mouse serum for ChAT. No immuno-staining was noted after any of the control procedures.

\section{Interleukin $3(I L-3)$ treatment}

Before fixation, IL-3 was used to enhance the ChAT activity in the gland tissue. IL-3 treatment was tested by two methods. 1) The removed glands were treated with IL-3. They were dissected in calcium and magnesium-free Hank's balanced salt solution, and then incubated in Eagle's medium containing IL-3 (50 $\mathrm{U} / \mathrm{ml}$ : Cellular Products, USA) for $1 \mathrm{~h}$ at $37^{\circ} \mathrm{C}$. After incubation, the tissues were immersed in the fixative described later for $48 \mathrm{~h}$ at $4^{\circ} \mathrm{C}$. 2) $\mathrm{IL}-3(50 \mathrm{U} / \mathrm{ml})$ was injected directly into the submandibular gland and simultaneously administered by close-arterial infusion using a peristaltic pump at a rate of $50 \mu \mathrm{l} / \mathrm{min}$ for $30 \mathrm{~min}$. and then processed for ChAT immunohistochemical staining.

\section{Acetylcholinesterase histochemistry $(\boldsymbol{A C h E})$}

The method of Tuji and Larabi ${ }^{16)}$ was used for histochemical localization of AChE.

\section{5-hydroxydopamine (5-OHDA) treatment}

Prior to fixation, the rats received a single intraarterial injection of 5-OHDA (Sigma, $25 \mathrm{ng} / \mathrm{m} l$ ) dis- solved in $0.5 \mathrm{~m} l$ saline containing ascorbic acid $(0.4$ $\mathrm{mg} / \mathrm{m} l$ ) via a cannulated facial artery.

Treatment of the experimental animals followed the Guidelines for Animal Experiments at Osaka Dental University.

\section{Results}

\section{Light microscopy}

Light microscopy revealed ChAT immuno-reactive nerve cells in the submandibular ganglions (Fig. 1A). A dense network of ChAT-positive nerve fibers was observed within the blood vessel wall (Fig. 1B). Nerve bundles in the main duct showed strong immunoreactivity with ChAT antibodies. A number of immuno-reactive fibers were seen within the acini of the gland (Fig. 1C, D).

A fine network of AChE-positive nerves was found in the submandibular gland in association with acini and blood vessels (Fig. 2A). However, such diffuse staining was not seen by ChAT immuno-staining with IL-3 treatment (Fig. 2B).

\section{Electron microscopy}

Prior to ChAT immunohistochemical procedures without IL-3 treatment, the reaction of ChAT was weak $\left(\mathrm{Fig} .3 \mathrm{~A}_{1}\right)$. This was particularly true at the electronmicroscopic level (Fig. $3 \mathrm{~A}_{2}$ ), where the ChAT immuno-reaction produced inconclusive results when the former methods for the central cholinergic nerve were used, as described by Mizukawa ${ }^{17}$. However, ChAT immunohistochemical procedures combined with IL-3 treatment produced excellent immunostaining. Axons labeled by the ChAT-antibody were found adjacent to acinar cells (Fig. $3 \mathrm{~B}_{1}$ ). Cholinergic fibers were in close proximity to the outer blood vessels (Fig. $3 \mathrm{~B}_{2}$ ). ChAT-positive nerve bundles and terminals were found in the outer surface of acini and intercalated duct cells. DAB-reaction was enhanced by employing metallic ions (Fig. 4). After 5-OHDA treatment, vesicles of various sizes were found to be filled with a material of high electron density (Fig. $5 \mathrm{~A})$. Adrenergic fibers were seen in the outer blood vessels (Fig. 5B).

Prior treatment with 5-OHDA revealed fibers and 


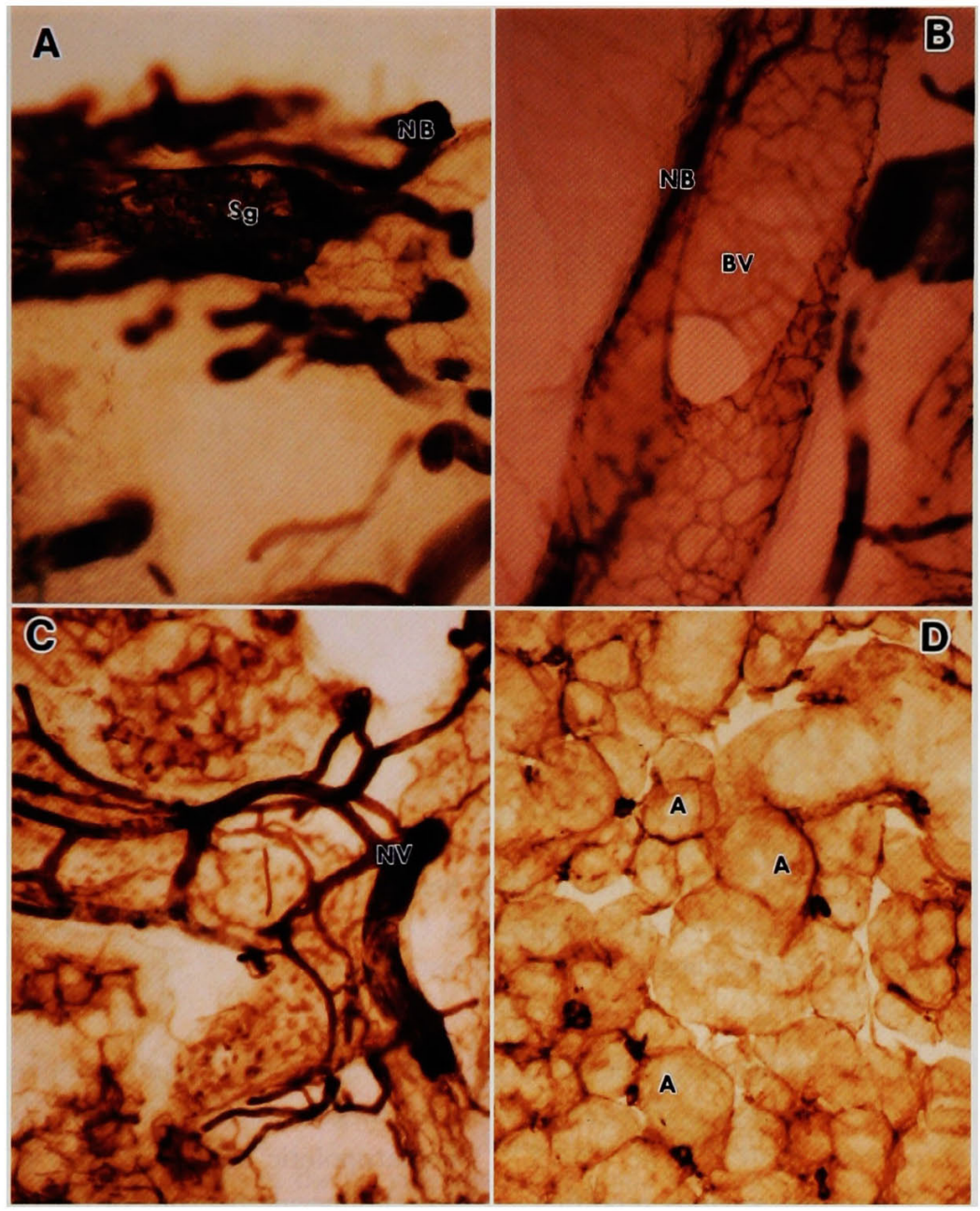

Fig. 1 Light photomicrographs of the submandibular gland with ChAT immuno-staining.

A : Reaction products are seen in the submandibular ganglion (SG) $(X$ 100). B : In nerve bundles (NB) along the wall of the main duct, and within the blood vessel $(B V)$ wall $(\times 100)$. C : Nerve bundles $(\mathrm{NB})$ form a fine network in the gland $(\times 100)$. D : ChAT positive nerve bundles are found within acini (A) and blood vessels $(\times 250)$.

their varicosities containing small dense-cored vesicles. ChAT immuno-staining with colloidal gold particles visualized other axons (Fig. 6), indicating the presence of both adrenergic and cholinergic terminals. Adrenergic and cholinergic terminals that often seem to converge on the same acinar cell were seen running closely together in the glands.

\section{Discussion}

Immuno-reaction with the monoclonal anti-ChAT antibody is well established as a specific method for localizing cholinergic nerves ${ }^{18}$. However, detection of immuno-reactivity is considered very difficult, particularly in the peripheral nervous system, because the antigen is very labile ${ }^{19)}$ and highly soluble ${ }^{20)}$.

In this study, ChAT could not be detected in the 


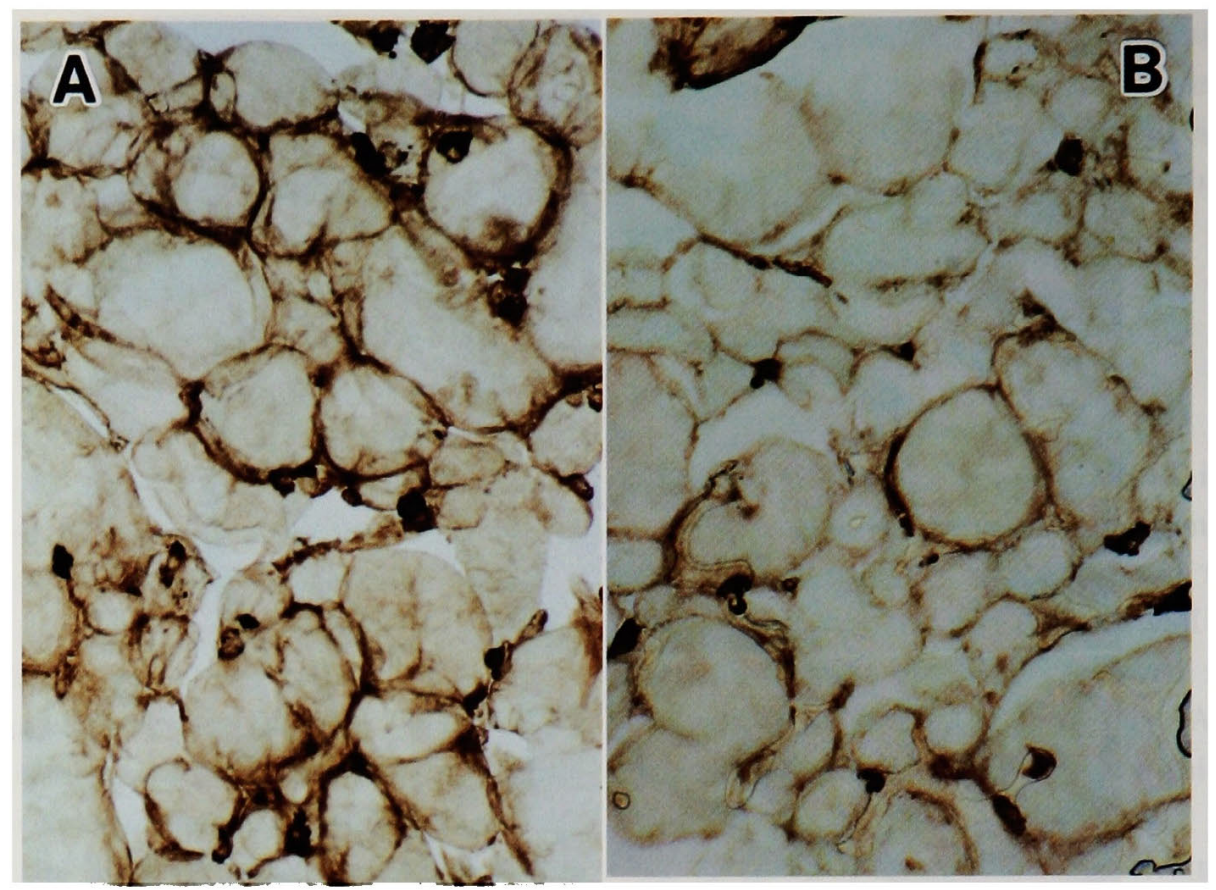

Fig. 2 Light photomicrograph of the rat submandibular gland with AChE histochemistry and ChAT immunohistochemistry.

A : The AChE reaction covers a wider area $(\times 250)$ than $B$ : ChAT staining $(\times$ 250). Overstaining was observed in AChE histochemistry.

submandibular gland using the immunohistochemical method of Mizukawa et al. ${ }^{17}$, which is frequently applied to the central nervous system. The ChAT reaction was too weak. Therefore, various modifications of the method were tested. Ojima et al. ${ }^{21)}$ noted that mild fixation and prolonged incubation are necessary for a successful reaction. Accordingly, the concentrations of glutaraldehyde and the fixing time were minimized to prevent reduction of ChAT activity.

Several types of monoclonal antibodies were used as the primary antibody for ChAT. Monclonal antibodies derived from rat-mouse hybrid cells (Boehlinger-Mannheim) showed the highest reactivity. Our preliminary tests gave the best results with an incubation time of $48 \mathrm{~h}$ at $4^{\circ} \mathrm{C}$, and fixations described in this paper.

It has been reported that ChAT activity in the sialaden varies with the age of the host. According to Ekström ${ }^{22)}$, ChAT activity in the submandibular gland of rats increases with age, and reaches a plateau at 3 months when the body weight is $250 \sim 300 \mathrm{~g}$. In this study rats aged $12 \sim 16$ weeks were used.

Kamegai et al.$^{23)}$ found that IL-3, a growth factor of hematopoietic cells, was also a novel trophic factor for cholinergic neurons of the central nervous system of mice and rats. IL-3 accelerates the extension of axons and ChAT activity specifically found in cholinergic neurons. IL-3 was directly injected into the submandibular gland and simultaneously into the glandular artery. This markedly enhanced the immunohistochemical reaction of ChAT. It was found that treatment with IL-3 was the most effective method for immunohistochemical detection of cholinergic neurons in the peripheral nervous system. Various modifications were also attempted.

In addition, pre-treatment with papain was also done prior to incubation of the specimen with the primary antibody to enhance the specific immunological staining. The DAB-reaction was also enhanced by employing metallic ions, as has been recommended by several protocols ${ }^{12,24,25)}$, using a combination of $\mathrm{Co}^{2+}$ and $\mathrm{Ni}^{2+}$ ions added to the DAB medium. These modifications made it possible to 


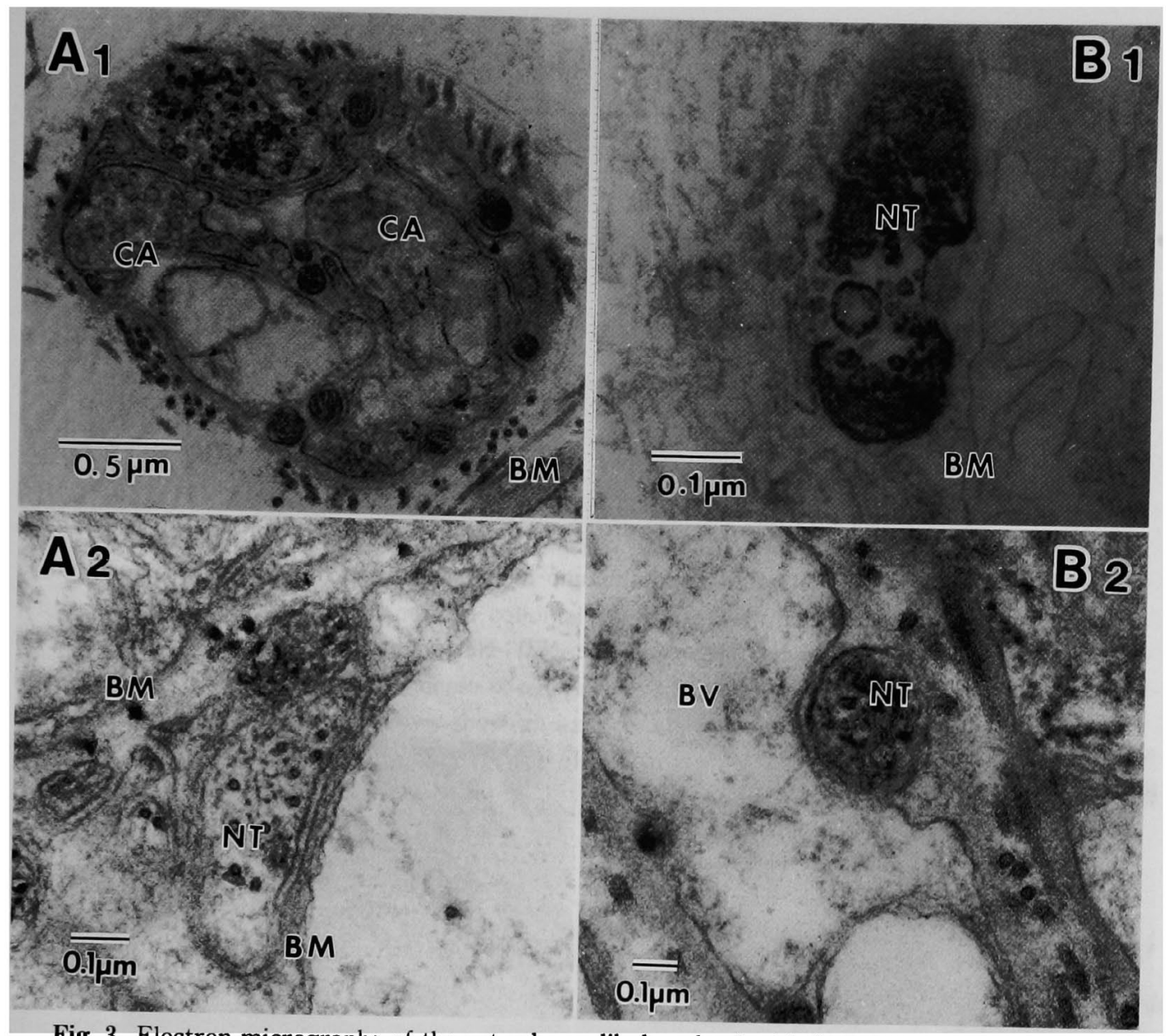

Fig. 3 Electron micrographs of the rat submandibular gland with ChAT immuno-staining. $\mathrm{A}_{1}$ : With the former technique, immuno-reaction was not detected in the cholinergic axon (CA), which contained vesicles without cores. $A_{2}$ : The nerve terminal. $B_{1}:$ A ChAT positive nerve axon is seen adjacent to acinar and intercalated duct cells. $B_{2}$ : This is the area around a blood vessel.

BM : Basement membrane, NT : Nerve terminal, BV : Blood vessel

detect cholinergic neurons in the submandibular gland with an immunohistochemical method.

5-OHDA is an analogue of dopamine that replaces endogenous stores of the amine and gives rise to a core of very high electron density in synaptic vesicles and nerve fibers. 5-OHDA labeled terminals are monoaminergic ${ }^{26)}$. It is a "false neurotransmitter" for the cytochemical demonstration of catecholaminecontaining neurons that retain a high-affinity amine uptake mechanism for catecholamines ${ }^{27}$. Following treatment with 5-OHDA, nearly all the small vesicles and many of the large ones in the adrenergic or dopaminergic neurons exhibited highly electron dense contents $^{28)}$.

Cored vesicles were found in the nerve fibers and varicosities in the vicinity of the acinar cells, duct cells and blood vessels. Our findings agreed well with previous reports on the distribution of 5-OHDA reactive fibers in the rat submandibular gland. Garrett $^{5}$ found axons with and without dense cored small vesicles within acinar cells and their associated myoepithelial cells, as well as in the outer smooth muscle cells of glandular blood vessels.

In the present study, two different methods were used to detect ChAT innervation at the electronmicroscopic level. A treatment of 5-OHDA combined 


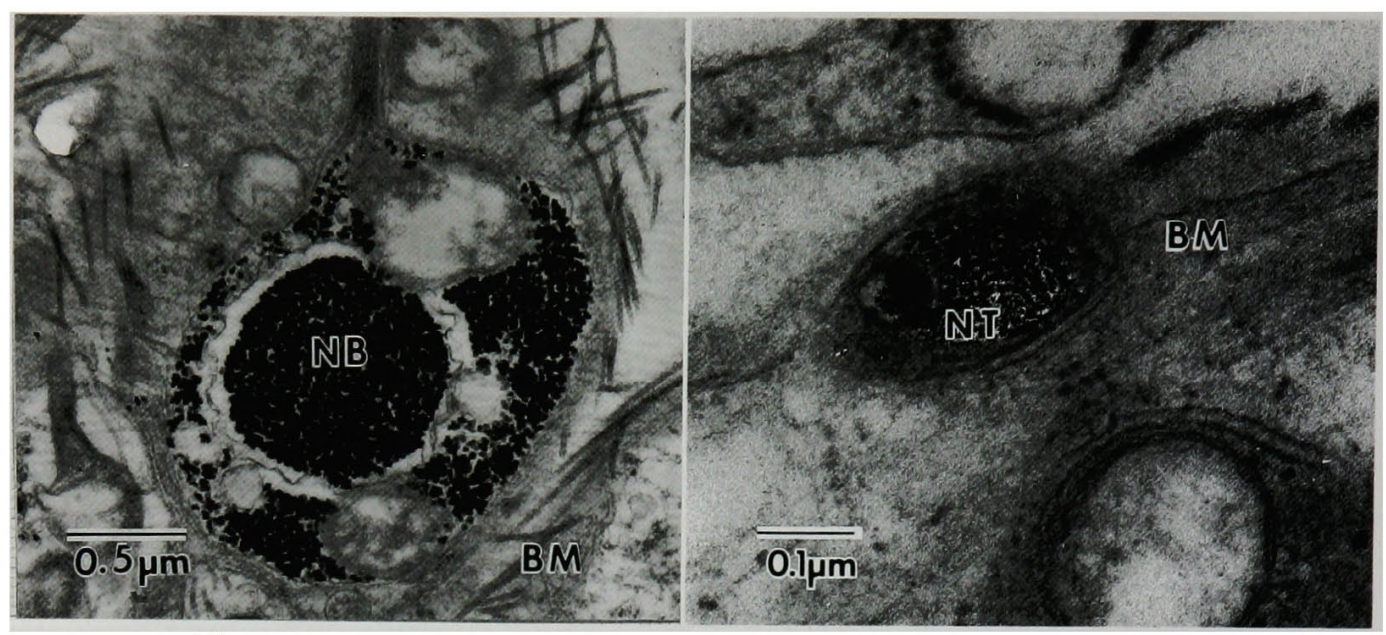

Fig. 4 Electron micrographs of the gland with ChAT immuno-staining.

Details are seen in the IL-3 treated gland. Immuno-staining enhances the visible DAB-reaction by employing metalic ions.

BM : Basement membrane, NB : Nerve bundle, NT : Nerve terminal

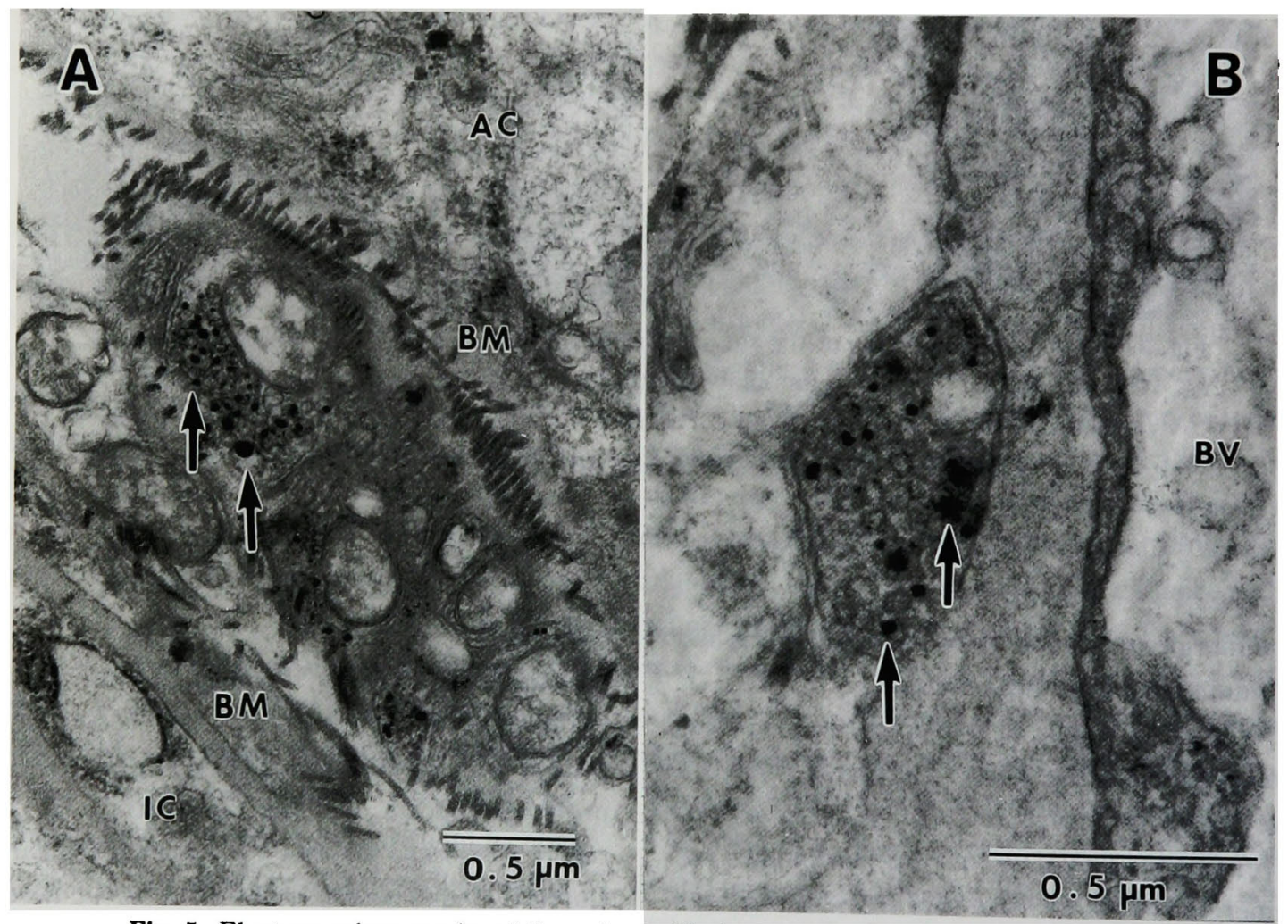

Fig. 5 Electron micrographs of the submandibular gland with 5-OHDA treatment.

A : Note the nerve varicosities that contain dense-cored vesicles of various sizes (arrows) within the acinar and intercalated duct cells labeled by 5-OHDA. B : The same can be observed around blood vessels.

AC : Acini, IC : Intercalated duct, BM : Basement membrane, BV : Blood vessel 


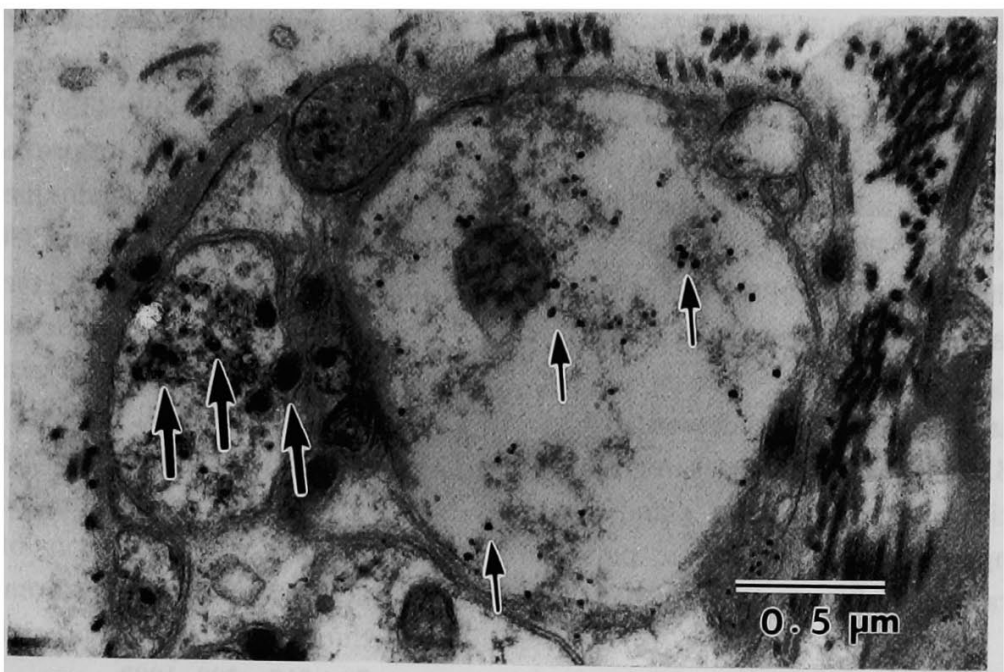

Fig. 6 Electron micrograph of the submandibular gland with ChAT immuno-colloidal gold vesicles and 5-OHDA pretreatment. The large arrows show nerve varicosities containing dense cored vesicles of various sizes, while the small arrows show an axon in close contact labeled with colloidal gold particles of the same size.

with postembedding using the protein A-colloidal gold method gave the best results. In sections processed after the animals were treated with 5-OHDA and immunocytochemical staining for ChAT, nerve terminals containing cored vesicles of various sizes were seen in contact with ChAT immuno-staining nerve fibers.

Using the protein A-colloidal gold immunocytochemical procedure, techniques for double immunostaining were applied in an attempt to distinguish aminergic and cholinergic nerve fibers in the submandibular gland.

Various neurotransmitters and modulators contained in neurons have been used to immunohistochemically detect nerve fibers. Methods I developed here for detection of cholinergic nerve fibers will be useful in classifying the three different nerve systems, i.e. cholinergic, adrenergic and primary sensory fibers. If access of these nerve terminals can be detected to the gland cells and blood vessels, it will be possible to investigate neuropeptides by observing the condition of peptides released from nerve terminals.

\section{Acknowledgments}

I am deeply indebted to Professor Y. Yoshida for his valuable comments and advice, and to Dr. K. Uchihashi (Department of Physiology, Osaka Dental University) for advise on the immunohistochemical procedures.

This study was supported in part by a grant-in-aid from the Osaka Dental University Research Fund for 1993.

Part of this work was presented at the 72nd Annual Meeting (March 30, 1995, Nagoya) of the Japanese Physiological Society.

\section{References}

1) Chibuzo, G. A. and Cummings, J. F. : Motor and sensory centers for the innervation of mandibular and sublingual salivary glands: a horseradish peroxidase study in the dog. Brain Res. 189: 301 $\sim 313,1980$.

2) Lundberg, J. M., Hökfelt, T., Schultzberg, M., Uvnäs-Wallensten, K., Köhler, C. and Said, S. I. : Occurrence of vasoactive intestinal polypeptide 
(VIP)-like immunoreactivity in certain cholinergic neurons of the cat : evidence from combined immunohistochemistry and acetylcholinesterase staining. Neuroscience. $4: 1539 \sim 1559,1979$.

3) Emmelin, N.: Nerve interactions in salivary glands. J. Dent. Res. 66 : 509 517, 1987.

4) Garrett, J. R. : The proper role of nerves in salivary secretion : a review. J. Dent. Res. $66: 387$ 〜397, 1987.

5) Garrett, J. R., Suleiman, A. M., Anderson, L. C. and Proctor, G. B. : Secretory responses in granular ducts and acini of submandibular glands in vivo to parasympathetic or sympathetic nerve stimulation in rat. Cell. Tissue Res. 264:117 $\sim 126,1991$.

6) Bernard, C. M. : Recherches expérimentales sur les ganglions du gland sympathique. Compt. Rend. Acad. Sci. $55: 341 \sim 350,1862$.

7) Kujat, R., Rose, C. and Wrobel, K. H. : The innervation of the bovine ductus deferens : comparison of a modified acetylcholinesterase-reaction with immunoreactivities of cholineacetyltransferase and panneuronal markers. Histochemistry. 99 : 231 239, 1993.

8) Kimura, H., McGeer, P. L., Peng, J. H. and McGeer, E. G. : The central cholinergic system studied by choline acetyltransferase immunohistochemistry in the cat. J. Comp. Neurol. $200: 151$ 〜201, 1981.

9) Shida, T., Ueda, Y., Ishida-Yamamoto, A., Senba, E. and Tohyama, M. : Enkephalinergic sympathetic and parasympathetic innervation of the rat submandibular and sublingual glands. Brain Res. 555 : 288 294, 1991.

10) Eckentein, F. and Sofroniew, M. V. : Identification of central cholinergic neurons containing both choline acetyltransferase and acetylcholinesterase and of central neurons containing only acetycholinesterase. J. Neurosci. 3: 2286 2291, 1983.

11) Cuello, A. C. and Sofroniew, M. V. : The anatomy of the CNS cholinergic neurons. Trends. neurosci. $7: 74 \sim 78,1984$.

12) Tago, H., McGeer, P. L., Bruce, G. and Hersh, L. B. : Distribution of choline acetyltransferasecontaining neurons of the hypothalamus. Brain Res. 415 : 49 62, 1987.

13) De Jong, A. S. H., Van Kessel-Van Vark, M. and Raap, A. K. : Sensitivity of various visualization methods for peroxidase and alkaline phosphatase activity in immunoenzyme histochemistry. Histochem. J. $17:$ 1119 1130, 1985.

14) Kushida, H.: An improved embedding method using ERL 4206 and Quetol 653. J. Electoron Microsc. $29:$ 193 194, 1980.

15) Brands, R., Koninkx-Peeters, R., Slot, J. W. and Geuze, J. J. : Immunocytochemistry on acid hydrolases in preputial gland cells. Cell Biol. Int. Rep. $4: 749,1980$.

16) Tsuji, S. and Larabi, Y. : A modification of thiocholine-ferricyanide method of Karnovsky and Roots for localization of acetylcholinesterase activity without interference by Koelle's copper thiocholine iodide precipitate. Histochemistry. $78: 317 \sim 323,1983$.

17) Mizukawa, K., McGeer, P. L., Tago, H., Peng, J. H., McGeer, E. G. and Kimura, H. : The cholinergic system of human hindbrain studied by choline acetyltransferase immunohistochemistry and acetylcholinesterase histochemistry. Brain Res. 379: 39 55, 1986.

18) Eckenstein, F. and Thoenen, H. : Production of specific antisera and monoclonal antibodies to choline acetyltranferase: characterization and use for identification of cholinergic neurons. EMBO. J. $1: 363 \sim 368,1982$.

19) Kimura, H., McGeer, P. L. and Peng, J. H. : Cholin acetyltransferase-containing neurons in the rat brain. In: Handbook of chemical neuroanatomy, vol 3. Classical transmitters and transmitter receptors in the CNS, part II. (edited by Björklund, A., Hökfelt, T. and Kuhar, M. J.), pp. 51 67, Inc. Elsevier, Amsterdam, New York, Oxford, 1984.

20) Salvaterra, P. M. and Vaughn, J. E. : Regulation of choline acetyltransferase. Int. Rev. Neurobiol. $31: 81 \sim 143,1989$.

21) Ojima, H., Yamasaki, T., Kojima, H. and Akashi, A. : Immunohistochemical conditions for staining choline acetyltransferase-containing axon terminals in the rat. Stain Technol. 63: 137 143, 1988.

22) Ekström, J. : Choline acetyltransferase activity and weight of salivary glands in rats at different ages. Acta Physiol. Scand. $98: 185 \sim 191,1976$.

23) Kamegai, M., Konishi, Y. and Tabira, T. : Trophic effect of granulocyto-macrophage colonystimulating factor on central cholinergic neurons in vitro. Brain Res. $532: 323 \sim 325,1990$. 
24) Adams, J.C.: Heavy metal intensification of DAB-based HRP reaction product. J. Histochem. Cytochem. $29: 775,1981$.

25) Scopsi, L. and Larsson, L. I. : Increased sensitivity in peroxidase immunocytochemistry : a comparative study of a number of peroxidase visualization methods employing a model system. Histochemistry. $84: 221 \sim 230,1986$.

26) Richards, J.G. and Tranzer, J. P. : The ultrastructural localization of amine storage sites in the central nervous system with the aid of a specific marker, 5-hydroxydopamine. Brain Res. $17: 463 \sim 469,1970$.

27) Richards, J. G. and Tranzer, J. P. : Localization of amine storage sites in the adrenergic cell body : a study of the superior cervical ganglion of the rat by fine structural cytochemistry. J. Ultrastr. Res. 53:204 216, 1975.

28) Tranzer, J. P. and Thoenen, H. : Significance of "empty vesicles" in post-ganglionic sympathetic nerve terminals. Experientia. 23: 123 124, 1967. 